

\section{THE PROBLEM OF VERBALIZATION OF EMOTIONS IN SCIENTIFIC DISCOURSE}

The article is focused on the theoretical foundations of emotionality, ways and means of verbalising a human's emotional state. Emotions, as an inseparable part of any person's human life, are reflected in language. Language objectifies feelings and emotions through specific words denoting the names of the speakers' experiences. People use language to express their emotional state.

The opposing approaches to the definition of the scope of the notion of emotive vocabulary and its components: the vocabulary of emotions and the emotional vocabulary have been characterised. The definitions of the notions of "emotionality», "emotional breadth» and «expressiveness» have been characterised. It has been established that there is no clear differentiation of the notions of «feeling», "emotion», «internality», "emotional state», "emotional experience», so they are considered to be synonyms up to now.

Verbalization of emotion is the verbal expression of a speaker's emotional state, which occurs in a particular way and by appropriate means. It has been determined that the ablution of emotion closely interacts with its non-verbal expression, which remains quicker and more qualitative than the verbal expression.

The generalization of the classifications of emotion ablutions has shown that the kind of mode of emotion expression depends on the use of emotion vocabulary and emotional vocabulary in the utterance. Names of emotions and feelings in a text indicate a primary, explicit mode, and emotional vocabulary indicates a secondary, implicit mode. The language levels are characterised by unequal potential for expressing a person's emotional state. The lexical and syntactic levels are the most productive in terms of the number of means, while the phonetic level is the least productive.

The level of verbalization of emotional state is characterized, the depth of which depends on the speaker's ability to analyze his inner state and to express it by appropriate linguistic means. The uncertainty in the definition of definitions concerning the problem of the theory of emotions, as well as the multiplicity of approaches to the question of classification of ways and means of verbalization of human experiences leave the problem of «language and emotions» relevant to this day.

Key words: emotions, emotionality, vocabulary of emotions, emotional vocabulary, verbalization of emotions.

Постановка проблеми. У сучасній лінгвістиці одним із пріоритетних підходів до вивчення мови став принцип антропоцентризму, що зумовило зацікавленість лінгвістів проблемами емотивності тексту. Людські емоції, як явище суб'єктивне, складне та багатогранне, виступають об'єктом дослідження багатьох наук: психології, фізіології, нейробіології, філософії, лінгвістики, культурології, психіатрії, антропології. Саме такий міждисциплінарний підхід до проблеми мови та емоцій дає змогу розглянути це питання з різних боків. Попри значні здобутки в сфері лінгвістичного вивчення емоцій, питання теорії емоцій, їх концептуалізації, семантизації та вербалізації і досі залишаються актуальними та найбільш складними для дослідження.

Аналіз досліджень. Лінгвістичне вивчення емоцій почалося 3 дискусії між мовознавцями (М. Бреалем, К. Бюлером, Е. Сепіром, Г. Гійомом, Ш. Баллі) щодо того, чи повинне мовознавство займатися студіюванням емоцій. Довгий час вчені були неодностайними у цьому питанні. К. Бюлер, Е. Сепір та Г. Гійом вважали, що домінантною в мові $є$ когнітивна функція, а тому вони заперечували вивчення лінгвістикою емоційного складника. А от Ш. Баллі та М. Бреаль вважали, що вербалізація емоцій - це одна 3 найголовніших функцій мови (Шаховский, 2008: 5).

Емоції стають об'єктом дослідження мовознавства в кінці 80-х років XX століття після того, як у 1987 р. на IV Міжнародному конгресі лінгвістів у Берліні Ф. Данешем було виголошено доповідь щодо емоційного аспекту мови, у якій науковець доводив тісний взаємозв'язок когнітивного та емоційного аспектів у мові. Проблема «мова та емоції» була однією з найпріоритетніших на той час у лінгвістиці: з'явилося чимало статей та монографій, було захищено низку кандидатських дисертацій на матеріалі різних мов (Шаховский, 2009: 32).

На сучасному етапі розвитку наукової думки проблема «мова та емоції» також активно розробляється українськими та зарубіжними дослідниками. Теоретичні засади лінгвістики емоцій, зокрема мовної репрезентації та вербалізації емоцій, розробляють В. Шаховський, В. Апресян, Д. Трунов, С. Петренко, М. Гончарук, Н. Сем'янків, I. Мац, О. Малиненко. Значна частина лінгвістів досліджує проблеми вербалізації емоційних станів на матеріалі іноземних мов - Н. Цинтар, I. Баженова, Н. Позднякова, Г. Харкевич. Вивченням репрезентації емоційного досвіду на основі українських прозових текстів займається I. Кость. Незважаючи на значний інтерес дослідників до об'єктивації людських переживань, усе ж залишається нерозв'язаною низка питань, зокрема відсутнє єдине трактування змісту та обсягу поняття «емотивної лексики», співвідношення «лексики емоцій» та «емоційної лексики». Досі не випрацювано єдиної класифікації способів та засобів вербалізації емоцій. 
Мета статті - узагальнити погляди дослідників на проблему емотивності тексту, а також систематизувати різні класифікації способів та засобів вербалізації емоційного стану людини.

Виклад основного матеріалу. Людські емоції мають найпотужніший вияв саме в мові та в мовленні, адже комунікативний акт взаємодії мовців передбачає не лише передачу інформації, знань, ідей, а й обмін емоціями, взаємозараження переживаннями та почуттями. Особливість мовлення в тому, що воно суб'єктивне, адже кожен адресант добирає свої засоби вираження думок та почуттів залежно від комунікативної мети, тому мова не може функціонувати поза емоціями (Цинтар, 2018: 17).

Як слушно зазначає Л. Бабенко: «Емоції пронизують життя людини, вони $\epsilon$ супутниками будь-якої людської діяльності, емоції - важлива частина людського існування. Без емоцій важко уявити і саму людину, і іï діяльність» (Бабенко: 1989, 3). У цьому контексті актуальне твердження В. Шаховського, що «людина не лише hото sapiens, але й homo sentiens, тому що багатьма ii діями керують емоції» (Шаховский, 2009: 29).

Л. Бабенко вважає, що емоції на мовно-мовленнєвому рівні можуть мати подвійний вияв. По-перше, вони постають у мовленні як емоційне забарвлення, що $є$ наслідком прориву емоційного стану мовця в його мовлення. По-друге, емоції відображаються мовними знаками як об'єкти дійсності (Бабенко: 1989, 11). Така подвійність спричинилася до розмежування термінів «лексика емоцій» та «емоційна лексика», що позначають два різні класи емотивної лексики. Лексика емоцій зорієнтована на об'єктивацію емоцій у мові. Вона виконує номінативну функцію, адже до цієї категорії належать слова, що слугують назвами емоцій, наприклад: «радість», «любов», «страх», «гнів». Емоційна лексика слугує засобом вираження емоційного стану мовця, а тому виконує експресивну функцію (Бабенко: 1989, 12).

К. Тимофєєв та О. Бабкін зазначають, що лексика емоцій, тобто назви почуттів та настрою, наприклад: «любов», «страх», «ніжність», а також слова, які виражають лексичну оцінку певного явища, наприклад: «добрий», «злий», «страшний», «милий» не мають нічого спільного з емоційною лексикою. Дослідники вважають, що в таких словах відсутнє будь-яке емоційне забарвлення. Вони відстоюють думку, що до емоційної лексики належать винятково слова, у яких емоції виражаються не лексично, а за допомогою емоційно забарвлених морфем, наприклад: «столик», «квіточка», «хатинка» (Тимофеев, Бабкин, 1955: 131).
У річищі проблеми «мова й емоції» варто також акцентувати на розрізненні понять «емоційність», «емотивність» та «експресивність». Підтримуємо позицію В. Маслової, яка кваліфікує емоційність як психологічну характеристику особистості, стан та рівень розвитку її емоційної сфери, а емотивність як лінгвістичну характеристику слова, речення, що здатна [...] викликати в мовної особистості відповідні емоції (Маслова, 2004: 227). Іншу природу має експресивність: це здатність мовних засобів впливати на реципієнта й викликати в нього певні емоції (Гончарук: 34-35).

Очевидним $є$ й те, що вчені по-різному потрактовують зміст та обсяг лексики емоиій, емоиійної лексики та загалом емотивної лексики. 3 цього приводу Л. Бабенко, зокрема, дискутує з В. Шаховським, доводячи, що найбільший потенціал має саме лексика емоцій, тому що «...емотивні сенси у ній експліцитні, найбільш стійкі та стабільні. Ці слова - безпосередні знаки емоцій» (Бабенко, 1989: 13). Саме таку лексику дослідниця вважає власне емотивною.

Натомість В. Шаховський переконує, що власне емотивами є лише емоційні лексеми, оскільки саме вони семантично категоризують емоції. А лексиці емоцій дослідник кваліфікує як перехідну між власне емотивною та неемотивною, але зазначає, що лексика, яка називає емоції, потенційно тяжіє до емотивної, а не до нейтральної (Шаховський, 2009: 32).

Кожна людина щоденно певним чином впливає на інших людей і сама зазнає впливів, тобто переживає те, що з нею стається і те, що вона породжує сама. Зрозуміло, що людина має певне ставлення до того, що ії оточує, до своїх дій та до вчинків інших людей. Переживання цього ставлення людини до навколишнього світу формує сферу почуттів або емоцій людини. Отже, емоції людини - це їі ставлення до світу і до того, що вона сама відчуває та робить (Рубинштейн, 2000: 436).

У деяких випадках психологи розділяють поняття «емоції» та «почуття». Емоційні процеси вважаються такими, що спільні для людей та тварин, бо вони врівноважують стан організму та навколишнього середовища. Але людині також притаманні емоції, які виникають під час задоволення психологічних та соціальних потреб, тому такі емоції вважаються «вищими» та іноді називаються «почуттями» (Трунов, 2013: 102). Вслід за Д. Труновим (Трунов, 2013) та А. Залізняк (Кость, 2011), ми не будемо розмежовувати поняття «емоції», «почуття», «переживання», «емоційний / душевний / внутрішній стан», зважаючи на відсутність одностайності серед дослідників та чіт- 
кого визначення обсягу цих понять. Кваліфікуватимемо ці поняття синонімічними, а всі вияви емоційних реакцій називатимемо емоційними станами.

За Д. Труновим, вербалізація емоцій - це процес омовлення людиною своїх емоційних переживань та станів (Трунов, 2013: 102). Результати досліджень вербалізації емоційних станів людини доводять, що не існує єдиного способу та засобу для омовлення почуттів.

В. Шаховський, зокрема, вважає, що наявні дві семіотичні системи емоцій - «мова тіла» та «словесна мова», які перебувають у взаємодії, проте невербальна система перевершує вербальну у швидкості, ступені щирості та якості вираження емоцій у спілкуванні (Шаховский,2009: 33). Отже, хоч ми й висвітлюємо питання вербалізації емоцій, проте маємо пам'ятати, що омовлення почуттів невіддільне від їх фізичного вираження.

Є. Петренко слушно зазначає, що «в процесі комунікації можна виділити різні способи вербалізації емоцій, що передбачають таке: безпосередню вербалізацію власних емоційних станів мовця, опосередковану вербалізацію емоцій і метафоричну вербалізацію емоційних станів мовця» (Петренко, 2018: 81).

Розрізняють експліцитне та імпліцитне мовне позначення емоційного стану залежно від того, чи $є$ у вербальному вираженні почуттів вказівка на конкретну емоцію. Якщо до складу лексичних засобів входять назви почуттів, переживань, то це вважається експліцитним вираженням емоцій. Якщо ж вказівку на емоцію подано опосередковано, переважно за допомогою переносного значення, то таке вираження вважається імпліцитним (Кость, 2011: 280).

I. Кость пропонує розрізняти також первинну (денотативну, або категоріально-емотивну) i вторинну (диференційну) лексичну номінацію залежно від способу презентації емотивного смислу. Номінація вважається первинною, якщо наявна назва емоції. Якщо емоційний стан вербалізовано за допомогою переносних значень, то така номінація вторинна (Кость, 2011: 281).

Отже, розмежовують два способи вираження емоцій - невербальний (міміка, жести, пантоміміка) та вербальний (мовні засоби), які перебувають у тісному взаємозв'язку. Таку дихотомію визначено за критерієм наявності / відсутності у висловленні лексики емоцій. Якщо така лексика присутня, то спосіб вербалізації емоційного стану визначаємо як первинний, експліцитний, а якщо лексика емоцій відсутня, а емоційний стан виражено за допомогою переносних значень, то спо- сіб вербалізації емоцій вторинний, імпліцитний. Цікаво, що така вербалізація відбувається на всіх мовних рівнях: фонетичному, лексичному, фразеологічному, морфемному і синтаксичному. Кожен рівень має свою систему засобів вербалізації.

Найменший потенціал для вираження емоцій має фонетичний рівень. Вербалізацію емоцій на фонетичному рівні пов'язують із явищем звукосимволізму. Вважається, що існує зв'язок між певними звуками, які входять до складу слова, та значенням цього слова. Тобто звук може викликати в свідомості певне значення і стати його символом (Мац, 2003: 181).

Більшою продуктивністю для вербалізації емоційних станів характеризується морфемний рівень, тому що найчастіше слова набувають емоційного значення за допомогою морфем (Мац, 2003: 181). Яскравим прикладом $є$ зменшено-пестливі суфікси: -инк(а) (хатинка), -и(е) (деревие), -ичк(а) (сестричка).

Фразеологізми також часто використовують із метою вербалізації емоцій. Для цього послуговуються фразеологічними одиницями, у складі яких є лексика емоцій (огортає страх, мати дивний oстрах під шкірою), а також ті, які виражають емоції переносним значенням (шкрябає в сериі, кидати в жар) (Кость, 2011: 282).

I. Мац слушно зауважує щодо вираження емоцій на синтаксичному рівні: «...для вираження емоцій можуть вживатися окличні, питальні, еліптичні, інвертовані речення, вставні елементи. Чим вищий ступінь емоційного напруження, тим вищий ступінь дезорганізації синтаксичної структури. Перерваність, повтори, незакінченість синтаксичних конструкцій характерні для високої концентрації емоцій» (Мац, 2003: 181).

Кожен мовний рівень має певний потенціал та набір засобів у сфері вербалізації емоційних станів. Досі основним та найглибше вивченим вважається лексичний спосіб вербалізації емоцій.

Мовні засоби вираження емоцій різноманітні. В. Апресян поділяє всі мовні засоби вербалізації емоцій на чотири підтипи: 1) клішовані, закріплені за конкретною групою емоцій - емоційні вигуки (напр., ox!, ого! овва! для здивування), що можуть зберігати зв'язок із вокалізацією емоції та асоціюються 3 певним виразом обличчя; 2) вільні, контекстуально мотивовані способи вираження наприклад, пряма мова, яка вводиться дієсловом зі значенням емоції («Чому ж ти раніше мовчав?» - здивувалася вона); 3) спеціальні слова, які закріплені за певною групою емоцій, деякі 3 них можуть наближатися до вигуків («неймовірно» для захоплення); 4) стійкі конструкції, у 
яких прямо називаються емоції і використовуються різні емоційні слова (мені сумно, я вдячний) (Апресян, 2010: 27-28).

Як бачимо, засоби вираження емоційних станів неоднаково функціонують на різних мовних рівнях. Тому вважаємо за доцільне розглянути також класифікацію рівнів вербалізації емоцій Д. Трунова. Вчений вважає, що всі можливі висловлення людей про їхній емоційний досвід можна поділити на групи залежно від ступеня вербальної диференціації емоцій. Чим глибший рівень вербалізації, тим краще людина розуміє свої емоції (Трунов, 2013: 102).

«Нульовий» рівень вербалізації - це відсутність вербалізації, неспроможність виразити словами свій емоційний досвід. Якщо запитати людину про іï емоційний стан, то відповіді будуть такими: «Не знаю», «Не можу зрозуміти», «Усе нормально», «Ніяк», «Нейтрально». По суті людина такими фразами не відповідає на питання, а ухиляється від відповіді.

На першому рівні вербалізації людина починає визначати свій емоційний стан, хоч і робить це в загальних рисах, наприклад: «Мені погано (добре)», «Я задоволений (засмучений)», також мовець визначає ступінь свого переживання «дуже», «злегка», «трохи». Сюди ж відноситься i використання сленгових слів та жаргонізмів. Засоби, за допомогою яких виражаються емоції на першому рівні, найчастіше характеризуються багатозначністю, тому що одне слово може означати різні емоції, часто навіть протилежні.
На другому рівні вербалізації мовець конкретизує свій емоційний стан, використовуючи специфічну емотивну лексику: «Я боюся», «Мені соромно», «Я гніваюся». Чим більший запас емотивної лексики, тим краще мовець здатен виразити свій емоційний стан.

На третьому рівні відбувається не просто вираження певної емоції, а здійснюється аналіз певного індивідуального стану: «Я ображена. Мені стає ще більш образливо, тому що це близька людина. Я на нього сподівалася, а тепер я в ньому повністю розчарувалася». Такий рівень вербалізації найчастіше притаманний людям 3 високим рівнем емоційного інтелекту, часто це люди творчих професій - письменники, актори, режисери. Такі люди приділяють значну увагу своїм персонажам, часто рефлексують, а також мають великий запас емотивної лексики (Трунов, 2013: 103-104).

Висновки. Отже, аналіз теоретичних аспектів вербалізації емоційних станів виявив, що вчені по-різному трактують поняття «лексики емоцій» та «емоційної лексики» та їх співвідношення 3 емотивною лексикою. Наявні класифікації способів вербалізації емоцій по суті можна звести до умови про наявність чи відсутність конкретного позначення емоції у висловленні. Класифікації засобів вербалізації емоцій та їх трактування на окремих мовних рівнях мають неоднорідний характер, що спричиняє множинність підходів до аналізу мовної репрезентації емоцій.

\section{СПИСОК ВИКОРИСТАНИХ ДЖЕРЕЛ}

1. Апресян В. Ю. Речевые стратегии выражения эмоций в русском языке. Русский язык в научном освещеени. 2010. № 2. C. $26-57$.

2. Бабенко Л. Г. Лексические средства обозначения эмоций в русском языке. Свердловск: Издательство Уральского университета, 1989. $184 \mathrm{c.}$

3. Гончарук М. М. До проблеми поняття «емоція» у лінгвістиці. С. 30-39. URL: https://cutt.ly/aWukOzU

4. Кость I. Я. Механізми вербалізації емоційного стану людини в українському прозовому тексті. Вчені записки Таврійського національного університету ім. В. І. Вернадського. Серія «Філологія. Соиіальні комунікації». 2011 . № 4. T. 24 (63). Ч. 2. С. 279-283.

5. Маслова В. А. Когнитивная лингвистика. Минск: ТетраСистемс, 2004. 256 с.

6. Мац I. І. Різновиди емоцій та способи їх вербалізації (на матеріалі англійської мови). Вісник Житомирського державного університету імені Івана Франка. 2003. № 11. С. 181-183.

7. Петренко С. М. До проблеми вербалізації емоцій. Науковий вісник Міжнародного гуманітарного університету. Сер.: Філологія. 2018. № 37. Т. 4. С. 81-84.

8. Рубинштейн С. Л. Основы общей психологии. СПб: Издательство «Питер», 2000. 712 с.: ил.

9. Тимофеев К. А., Бабкин А. М. Рецензия на книгу Е. М. Галкина-Федорук Современный русский язык. Лексика: курс лекций. М. 1955. Вопросы языкознания. 1955. № 2. С. 125-133.

10. Трунов Д. Г. Уровни вербализации эмоционального опыта. Вестник Пермского университета. 2013. Вып. 1 (13). C. 102-107.

11. Цинтар Н. В. Вербалізація емоційних процесів в англійських прозових творах XXI століття. Закарпатські філологічні студії. 2018. Вип. 4. Т. 2. С. 17-21.

12. Шаховский В. И. Что такое лингвистика эмоций? Русистика. 2008. Вып. 8. С. 4-7.

13. Шаховський В. И. Эмоции как объект исследования в лингвистике. Вопросы психолингвистики. 2009 . № 9. C. $29-42$ 


\section{REFERENCES}

1. Apresyan V. Yu. Rechevye strategii vyrazheniya emocij v russkom yazyke [Speech strategies for expressing emotions in Russian]. Russian language in scientific coverage. 2010. Nr 2. pp. 26-57 [in Russian].

2. Babenko L. G. Leksicheskie sredstva oboznacheniya emocij v russkom yazyke [Lexical means of designating emotions in Russian]. Sverdlovsk: Izdatelstvo Uralskogo universiteta, 1989. 184 p. [in Russian].

3. Honcharuk M. M. Do problemy poniattia «emotsiia» u linhvistytsi [To the problem of the concept of «emotion» in linguistics]. pp. 30-39. URL: https://cutt.ly/aWukOzU [in Ukrainian].

4. Kost I. Ya. Mekhanizmy verbalizatsii emotsiinoho stanu liudyny v ukrainskomu prozovomu teksti [Mechanisms of verbalization of a person's emotional state in the Ukrainian prose text]. Scientific notes of V. I. Vernadsky Taurida National University. Series «Philology. Social communications». 2011. Nr 4. T. 24 (63). pp. 279-283 [in Ukrainian].

5. Maslova V. A. Kognitivnaya lingvistika [Cognitive linguistics]. Minsk: TetraSistems, 2004. 256 p. [in Russian].

6. Mats I. I. Riznovydy emotsii ta sposoby yikh verbalizatsii (na materiali anhliiskoi movy) [Examples of emotional and methods of verbalization (in English language materials)]. Visnyk of the Zhytomyr Ivan Franko State University. 2003. Nr 11. pp. 181-183 [in Ukrainian].

7. Petrenko Ye. M. Do problemy verbalizatsii emotsii [Before the problem of verbalization of emotions]. Scientific Bulletin of the International Humanitarian University. Series: Philology. 2018. Nr 37. T. 4. pp. 81-84 [in Ukrainian].

8. Rubinshtejn S. L. Osnovy obshej psihologii [Fundamentals of general psychology]. SPb: Izdatelstvo «Piter», 2000. 712 p. [in Russian].

9. Timofeev K. A., Babkin A. M. Recenziya na knigu E. M. Galkina-Fedoruk Sovremennyj russkij yazyk. Leksika: kurs lekcij. M. 1955 [Review of the book by E. M. Galkina-Fedoruk Modern Russian language. Vocabulary: a course of lectures. M. 1955]. Questions of linguistics. 1955. Nr 2. pp. 125-133 [in Russian].

10. Trunov D. G. Urovni verbalizacii emocionalnogo opyta [Verbalization levels of emotional experience]. Perm University Bulletin. 2013. Issue 1 (13). pp. 102-107 [in Russian].

11. Tsyntar N. V. Verbalizatsiia emotsiinykh protsesiv v anhliiskykh prozovykh tvorakh XXI stolittia [Verbalization of emotional processes in English prose works of the XXI century]. Transcarpathian philological studies. 2018. Issue 4. T. 2. pp. 17-21 [in Ukrainian].

12. Shahovskij V. I. Chto takoe lingvistika emocij? [What is emotional linguistics?] Russian studies. 2008. Issue 8. pp. 4-7 [in Russian].

13. Shahovskij V. I. Emocii kak obekt issledovaniya v lingvistike [Emotions as an object of research in linguistics]. Psycholinguistics issues. 2009. Nr 9. pp. 29-42 [in Russian]. 